\title{
THE MEANING OF EVOLUTION
}

\section{The Morphological Construction and}

Ideological Reconstruction of Darwin's Theory

\section{ROBERT J. RICHARDS}

Did Darwin see evolution as progressive, directed toward producing ever more advanced forms of life? Most contemporary scholars say no. In this challenge to prevailing views, Robert J. Richards says yes - and argues that current perspectives on Darwin and his theory are both ideologically motivated and scientifically unsound. Unlike most contemporary biologists or historians and philosphers of science, Richards holds that Darwin did concern himself with the idea of progress, or telos, drawing on the traditional embryological meanings of the terms "evolution" and "descent with modification" as he constructed his theory.

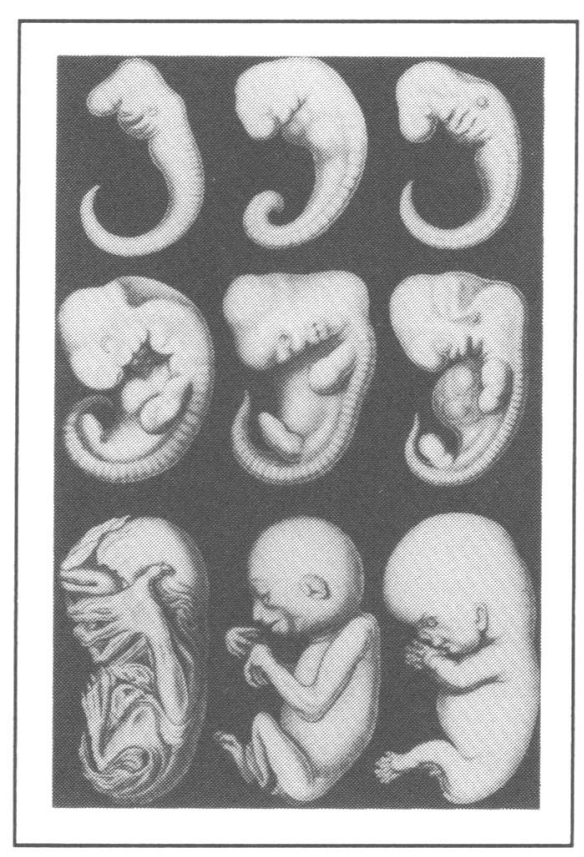

Cloth $\$ 19.95224$ pages

\section{The University of Chicago Press}




\section{CAMBRIDGE History of Science}

\section{A History of Regeneration Research}

Milestones in the Evolution of a Science Edited by CHARLES E. DINSMORE

In the 18 th century the phenomenon of animal regeneration captured the attention and imagination of the era's naturalists and intellectuals. This book chronicles this crucial evolutionary stretch in the history of developmental biology.

f30.00 net HB $0521392713 \quad 240 \mathrm{pp}$. 1992

\section{Goethe's History of Science} KARL J. FINK

As well as being a distinguished poet, Goethe was also a scientist, philosopher and historian. This book covers the activities of his mid-life, when he researched optics, colour theory and plant morphology, and contributed to writings in the history and philosophy of science.

f30.00 net HB 0521402115256 pp. 1992

\section{Promoting Experimental Learning}

Experiment and the Royal Society 1660-1727

\section{MARIE BOAS HALL}

This major new study analyses the contents of the meetings of the Royal Society during the first half-century of its existence, in an attempt to discover how far they fulfilled the expressed aim of promoting experimental learning. f35.00 net HB 0521405033224 pp. 1991

For further information please contact Science Publicity at the address below.

\section{Innovation in Maxwell's Electromagnetic Theory}

Molecular Vortices, Displacement Current, and Light

DANIEL L. SIEGEL

Maxwell's discovery of electromagnetic theory of light is among the most spectacular innovations in the history of physics. Here, Siegel analyses Maxwell's original texts and locates his work in the contents and traditions of early physics research.

f30.00 net HB $0521353653 \quad 290 \mathrm{pp}$. 1992

\section{Now in paperback}

\section{The Experimental Foundations of Particle Physics}

R. N. CAHN and G. GOLDHABER

'I believe this text to represent a major achievement in collecting, analysing and distilling for the reader, material forming an intensely exciting chapter in modern science.' D. H. Perkins, Nature f 15.00 net PB 0521424259448 pp. 1992

\section{The French Paracelsians}

The Chemical Challenge to Medical and Scientific Tradition in Early Modern Europe

ALLEN G. DEBUS

Here Allen Debus narrates an important episode whose contribution to the scientific revolution has been largely ignored: the long-standing contention between Paracelsians and Galenists.

f40.00 net HB $052140049 \times 247 \mathrm{pp}$. 1992

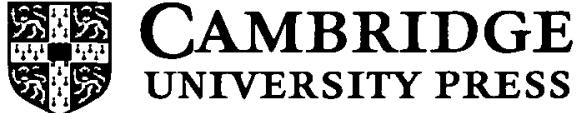

The Edinburgh Building, Cambridge CB2 2RU 
Galileo's Sidereus Nuncius in the seventeenth century proclaimed new and extraordinary discoveries to the intellectual community of his time. Rendering homage to the great Galilean tradition, Nuncius to-day provides an efficient means of in-
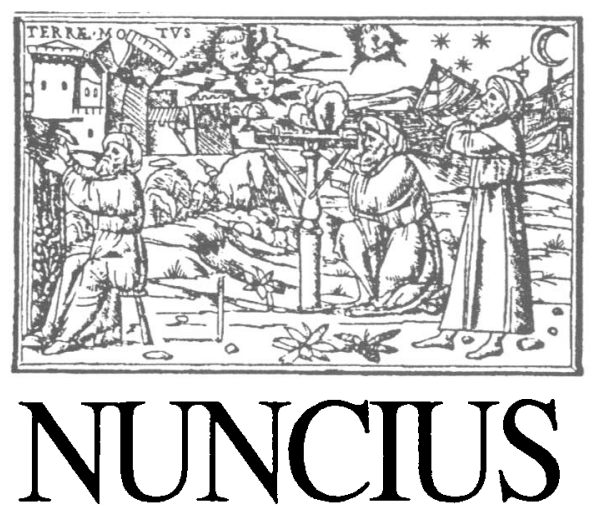

ANNALS FOR THE HISTORY OF SCIENCE

addition to articles on all aspects of the discipline, with the various methodological approaches which characterize it, Nuncius offers detailed bibliographical and archival documentation.

It will thus constitute and indispensable tool for ternational communication and infor- the critical assessment of a constantly mation for historians of science. In evolving discipline.

1991 foreign subscription price: Lire 90.000 (two issues per year)

Physis is the oldest Italian periodical specifically dedicated to the history of science. The journal welcomes contributions fromboth Italian and non-Italian authors and publishes articles in English, Italian, French, German and Spanish. All articles are accompanied by long summaries in English.

The journal covers all major aspects of the

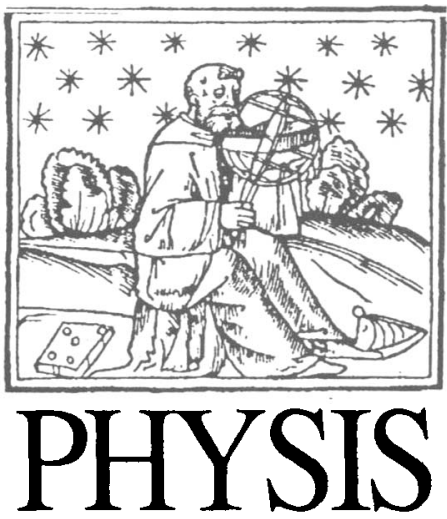

AN INTERNATIONAL JOURNAL FOR THE HISTORY OF SCIENCE the human sciences, scientific institutions and instruments, as well as the historiography of science and the history of relationships between science and philosophy, science and technology, science and society, and other interdisciplinary and border-line areas.

The journal does not specialise in any particular field or historical period; rather, history of Western sciences: History of Astronomy, Mathematics, Physics, Chemistry, Natural Philosophy, Earth Sciences, Natural History and the BioMedical and Life Sciences. It is also open to contributions in the history of

it offers a wider readership in the history of science a broad range of work on different subjects and periods while maintaining the highest standards of scholarship despite the variety of styles of approach of its contibutors

1991 foreign subscription price: Lire 85.000 (three issues per year)

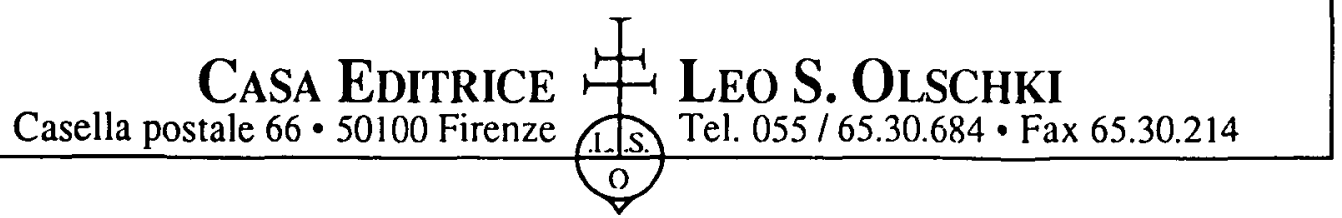




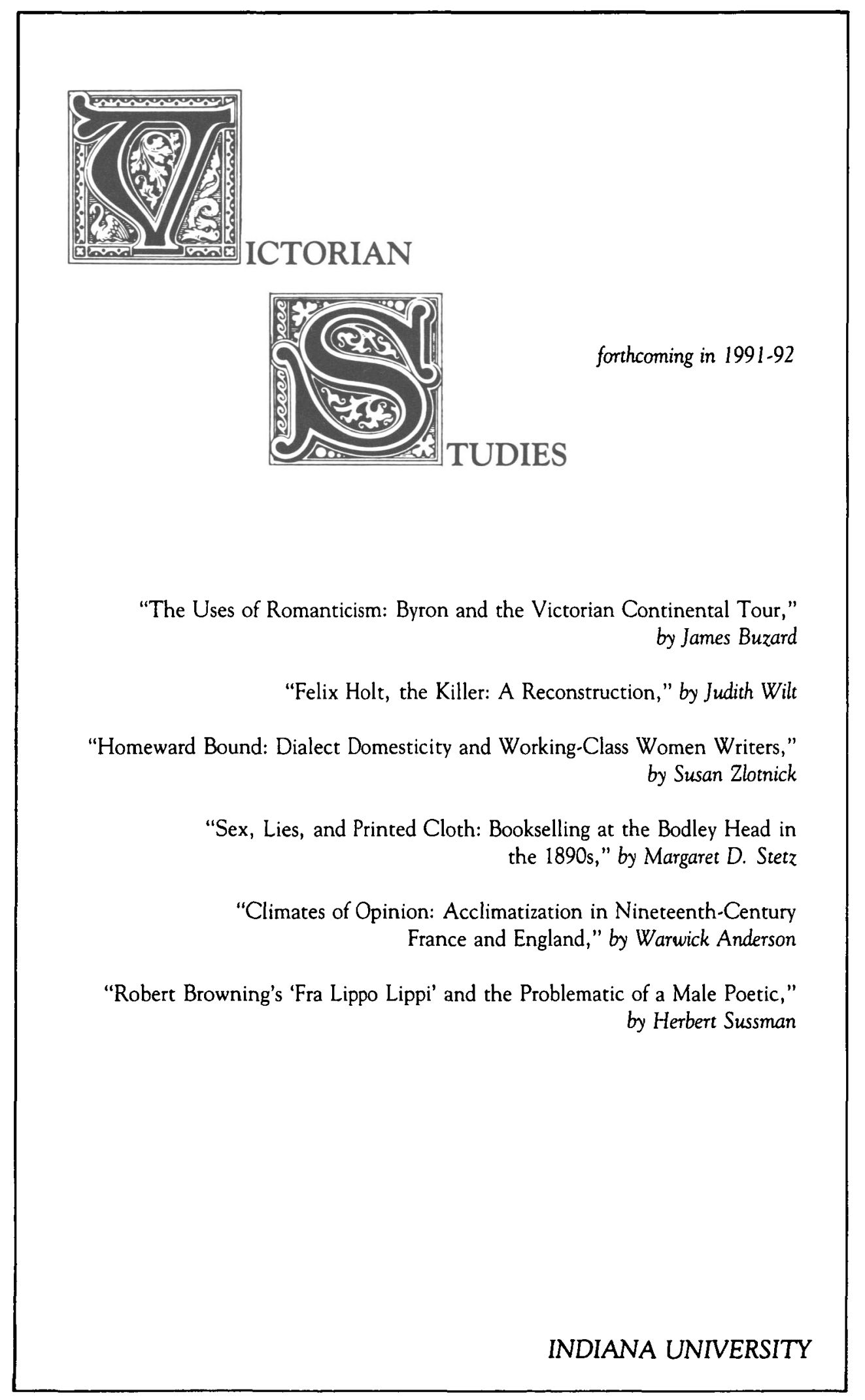




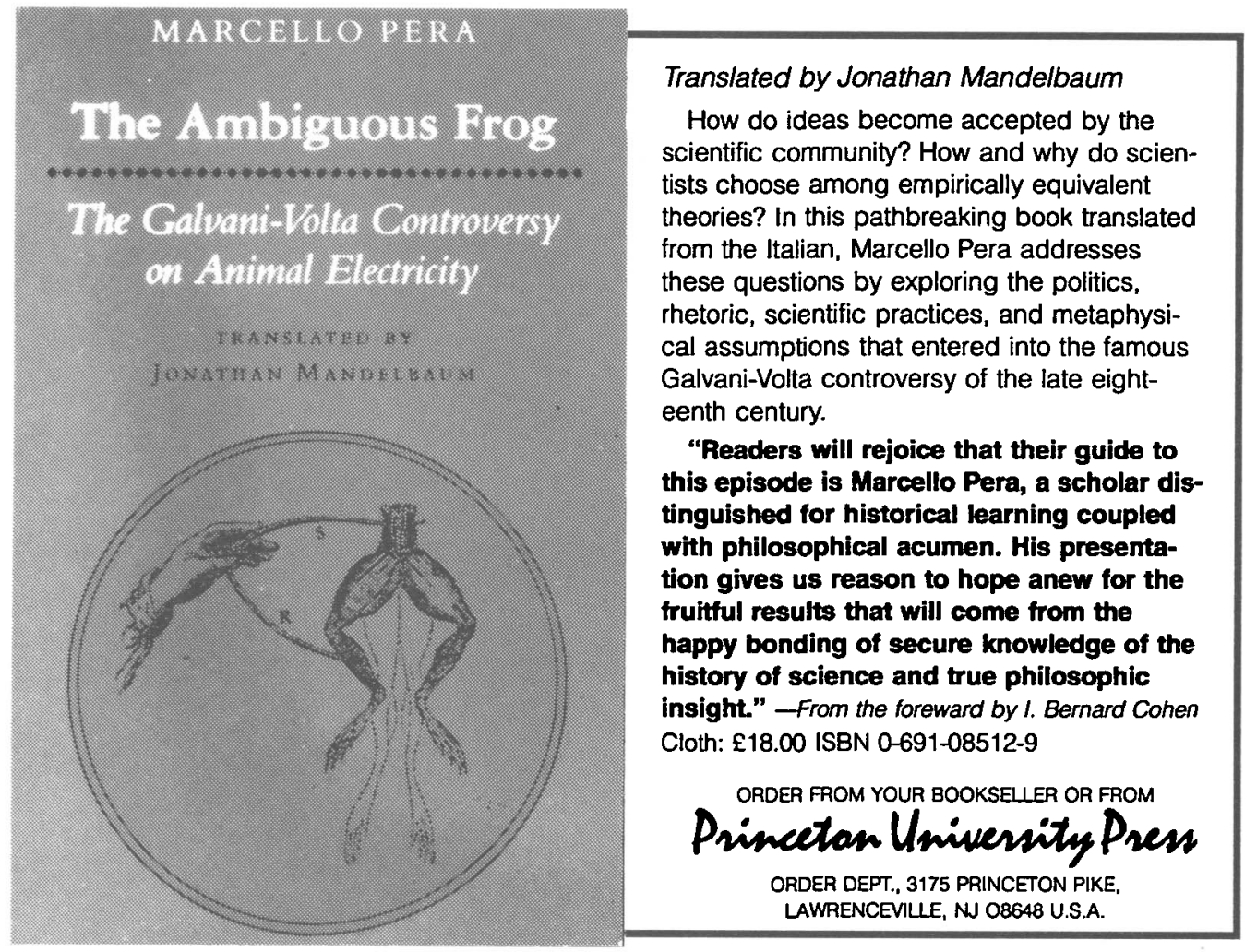


Membership of the Society, which normally includes a subscription to The British foumal for the History of Science, is open to all persons approved by the Council of the Society and elected at an ordinary meeting. The annual subscription for the membership year 1992 is $£ 18.50$ (\$40.00) or $£ 9.25$ (\$20.00) for associate membership, which includes students at centres of higher education. There is an Introductory Offer for ordinary members who pay $\mathcal{E}^{14.00}(\$ 30.00)$ for the first year. Applications for membership should be made on a form which is available from the Society's Executive Secretary at the address below.

Meetings: The Society mounts an ambitious programme of meetings. The pattern is flexible, but includes a threeday summer meeting, usually held at a different British University or Polytechnic each year. About four other meetings, lasting for between one and three days, are held during the year, sometimes devoted to a clearly defined theme or an important anniversary, and often arranged in conjunction with other scholarly societies.

The British Journal for the History of Science is the official organ of the Society. All correspondence on the contents of the Joumal should be addressed to the Editor, Dr J. H. Brooke, Department of History, University of Lancaster, Lancaster LA1 4YG, England. Books for review should be sent to the Reviews Editor, Dr John Henry, Science Studies Linit, Lniversity of Edinburgh, 34 Buccleuch Place, Edinburgh EH8 9JT.

Advertising : Contact the Journals Advertising Manager, Cambridge University Press, The Edinburgh Building, Shaftesbury Road, Cambridge CB2 2RU.

Other publications : BSHS Monograph Series is designed to allow the publication of monographic studies in the history of science quickly and cheaply. All correspondence on the subject of monographs, and any new suggestions for titles, should be sent to the Series Editor, Dr P. Weindling, Wellcome Unit for the History of Medicine, 45-47 Banbury Road, Oxford OX2 6PE, England. Monographs are available to members at a special price, post-free from the Society's Executive Secretary. Non-members may obtain them through bookshops, or post-free from the Executive Secretary. Titles are as follows:

2. The Letters of Georges Cutrer: A Summary Calendar. Ed. by Dorinda Outram. $1980 . £ 4.50 / \$ 10.00(£ 3.50 / \$ 8.00$ to members).

3. Rationality and Ritual: The Windscale Inquiry and Nuclear Decisions in Britain. By Brian Wynne. 1982. $£ 7.00 / \$ 15.00$ ( $55.00 / \$ 11.00$ to members).

4. The Royal Society and Its Fellows 1660-1700: The Morphology of an Early Scientific Institution. By Michael Hunter. 1982, reprinted 1985. Revised edition pending.

5. Francis Bacon's Natural Philosophy: A New Source. A Transcriplion of Manuscript Hardwick $72 A$ with Translation and Commentary. By Graham Rees, assisted by Christopher Upton. $1984 . £ 7.90 / \$ 17.00(£ 5.60 / \$ 12.00$ to members). 6. Archives of the British Chemical Industry, 1750-1914: A Handlist. By Peter J. T. Morris and Colin A. Russell. Contributing editor John Graham Smith. 1988. $£^{14.50 / \$ 31.00 ~(~} \AA^{9.00 / \$ 19.00}$ to members).

Each year, the Society publishes a List of Theses in History of Science in British universities. This is available free to members, and at $\mathcal{K}^{3.00}(\$ 6.00)$ to non-members on request to the Executive Secretary. Standing orders are accepted from members or non-members who wish to receive the list regularly.

The Society's Newsletter, an informal publication edited by Dr Frank A.J. L. James, RICHST, The Royal Institution, 21 Albemarle Street, London WIX 4BS, appears in February, June and October each year. It is free to members, $£ 6.00$ ( $\$ 12.00)$ for institutions and non-members.

Administrative business of the Society is handled by The Executive Secretary, Wing-Commander G. Bennett, 31 High Street, Stanford in the Vale, Faringdon, Oxfordshire SN7 8LH. The Society is registered in England as a Limited Company (No. 562208) and is a Registered Charity (No. 258854).

Copying: This journal is registered with the Copyright Clearance Center, 27 Congress Street, Salem, MA 01970. Organizations in the LSA who are also registered with the C.C.C. may therefore copy material (beyond the limits permitted by sections 107 and 108 of US copyright law; subject to payment to C.C.C. of the per-copy fee of 85.00 . This consent does not extend to multiple copying for promotional or commercial purposes. Code 0007-0874/92 $\$ 5.00+.00$.

ISI Tear Shet Sertice, 3501 Market Street, Philadelphia, Pennsylvania 19104, LSA, is authorized to supply single copies of separate articles for private use only.

For all other use, permission should be sought from Cambridge or the American branch of Cambridge L'niversity Press.

Back volumes are obtainable as follows: Volumes 18-23: Wing-Commander G. Bennett, 31 High Street, Stanford in the Vale, Faringdon, Oxon SN7 8LH. Volume 24 onwards from Cambridge Liniversity Press. 


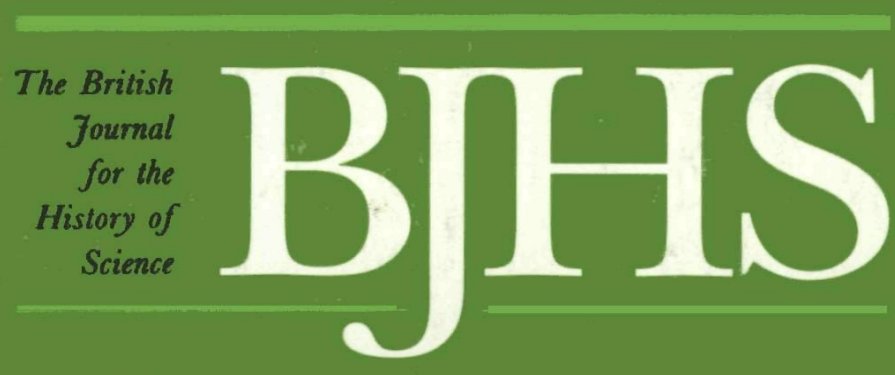

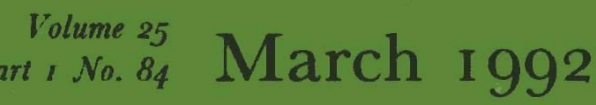

Organic Chemistry and High Technology, I $85^{0}-1950$

A special issue

Guest Editors: Anthony S. Travis, Willem J. Hornix and Robert Bud

I Foreword JOHN J. BEER

5 Technology in decline: a search for useful concepts. The case of the Dutch madder industry in the nineteenth century JOHAN SCHOT

27 Science's powerful companion: A. W. Hofmann's investigation of aniline red and its derivatives

ANTHONY S. TRAVIS

45 Why monopoly failed: the rise and fall of Société La Fuchsine HENK VAN DEN BELT

65 From process to plant: innovation in the early artificial dye industry

WILLEM J. HORNIX

91 The emergence of research laboratories in the dyestuffs industry, 1870-1900

ERNST HOMBURG

I 3 The British chemical industry and the indigo trade PETER REED

127 The zymotechnic roots of biotechnology ROBERT BUD

I45 The technology-science interaction: Walter Reppe and cyclooctatetraene chemistry

PETER J. T. MORRIS

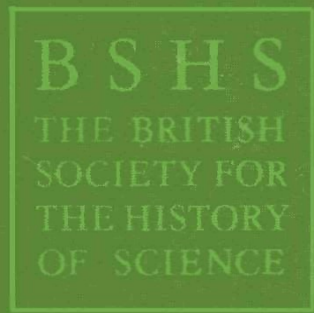

Published for The British Society for the History of Science

by Cambridge University Press 